\title{
Faculty Unionization and Salary Differentials in Ontario Universities
}

\author{
MICHAEL L. SKOLNIK and GERALDINE WOODFORD*
}

\section{RÉSUMÉ}

Cet article explore l'impact de la syndicalisation sur les différences salariales parmi les universités ontariennes en comparant les tendances dans les salaires moyens entre les institutions où les professeurs sont syndiqués et celles où ils ne le sont pas. L'étude porte sur la période de temps allant de 1975, année où la première université ontarienne se syndicalisa, à 1983, soit trois ans après que la dernière université à se syndicaliser le fit. L'étude montre que la hausse salariale moyenne (ajustée pour l'âge) dans les institutions syndicalisées n'est supérieure que de deux pour cent à celle des groupes non-syndiqués. Par ailleurs, d'autres données permettent de conclure que la syndicalisation n'a pas eu d'impact significatif sur les structures salariales relatives dans les universités ontariennes. On doit cependant nuancer cette conclusion en notant que la syndicalisation ne traduit pas forcément un syndicalisme revendicatif, que la présence de syndicats dans certaines universités a pu influencer le comportement salarial des institutions non-syndiquées, et que l'influence potentielle des syndicats professoraux a été limitée par les contrôles de salaire et les contraintes budgétaires en vigueur pendant la période à l'étude.

\begin{abstract}
This paper explores the impact of unionization on salary differentials among Ontario universities by comparing the trends in average salaries between those institutions which have certified bargaining units and those which do not. The principal time period considered is from 1975, when the first Ontario university became certified, to 1983, three years after the most recent faculty association to become certified did so. The age-adjusted average salary increase for the unionized institutions was found to be only about two per cent greater than for the nonunionized group. As well, other data presented led to the conclusion that unionization has not had a significant impact upon relative salary structures in Ontario universities. This conclusion is qualified by noting that certification may not be an effective indicator of unionization, that the presence of unions in some
\end{abstract}

*Higher Education Group, Ontario Institute for Studies in Education. 
universities may have influenced the salary behaviour of the nonunionized institutions, and that the potential influence of faculty unions was constrained by wage controls and funding limits during the period under investigation.

In their assessment of the impact of faculty collective bargaining in higher education, Baldridge and his colleagues observe that "debate has never ceased over the impact of unions on the wages of their members, particularly in comparison with the wages of their nonunionized counterparts" (1985:268). Reviewing the research on this question in the United States, the authors conclude that after appropriate adjustments are made the unionized faculty member earned on average $\$ 750$ to $\$ 900$ more per year in the 1970 s than his or her nonunionized counterpart; but that the discrepancy was decreasing and disappeared altogether when local cost of living differences were taken into account. Freeman (1978) estimated that the longitudinally adjusted salary advantage associated with unionization ranged between zero and five per cent. Jones notes that most of the early literature on the impacts of faculty unions concerned salary increases, but that while this research was abundant, it was also contradictory. He concludes that "the literature on salary reveals no convincing evidence that unions secure substantially better salaries than at nonunion colleges" (1986:184).

Although the relative incidence of unionization of university faculty has been greater in Canada than in the United States (Penner, 1978-79) we have been unable to find any studies of the effects of unionization upon earnings of faculty in Canadian universities. In fact, Ponak and Thompson (1983) note that "despite its importance, faculty collective bargaining ... has been the subject of little research in this country". The limited research which has been conducted upon unionization in Canadian universities has tended to focus upon the factors contributing to unionization and the effects of unionization upon faculty-administration relations, governance, and institutional character (Murray, 1985).

The lack of research on the impact of faculty unionization upon wages is perhaps explained by the fact that achievement of higher earnings does not appear to have been one of the major factors responsible for unionization in Canadian universities. Those who have written about the growth of unionization in Canadian universities have emphasized that unionization accelerated during a period in which faculty felt increasingly vulnerable to the whims of administration and boards as a result of the increase in the size and complexity of many universities, the levelling off of expansion, an increasingly tight labour market, and budgetary austerity (Carrigan, 1977:18-20). Savage, who was intimately involved in the process of unionization as an official of the Canadian Association of University Teachers, wrote that "faculty collective bargaining in Canada arose from faculty conviction that the university bureaucracy was increasing in scope and power at the expense of the faculty and that there was an eccentric use of presidential power ..." (1983:16). Adell and Carter cited reactions to the asymetry between 
administration and faculty influence and dissatisfaction with existing representational structures as the single most prominent cause of faculty interest in collective bargaining (1972:19). Penner observed that the rapid growth of universities led to the development of an employer bureaucracy which was increasingly alienated from the faculty and developed "hard-nosed administrative responses to faculty concerns" (p. 72). In a case study of unionization in an unnamed Atlantic region university, Garry (1978) reported that feelings of powerlessness, insecurity, and lack of full status as professionals were the major motivating factors, and desire for salary enhancement was a quite minor factor.

Insofar as the above characterizations of dominant faculty reasons for unionizing are correct, one might not expect salaries to have been given the highest priority in bargaining. In fact, Penner reported that the principal concerns of faculty in the bargaining process have been with development of due process procedures in areas such as hiring, promotion, and tenure; greater involvement of faculty in governance structures; and job security (p. 80). There is a general impression that faculty unions have been quite successful in negotiating contract provisions in these high priority areas. Carrigan, for example, concludes that faculty bargaining units have made great advances in these areas and that the biggest overall gain in union agreements is that agreed upon procedures and working conditions now have the force of law (p. 24).

While salary may not have been an area of the highest priority in unionization, it could hardly be considered a subject of indifference. Remuneration has been a central issue in the model of collective bargaining which universities have taken over from industry, and newspaper accounts suggest that salary is frequently in dispute when university bargaining discussions break down. For the past decade, briefs to Government from provincial faculty associations have indicated strong concern about the level of faculty salaries and possible salary erosion (Skolnik and Rowen, 1984). While due process, governance, and job security provisions can perhaps always be improved upon, the most substantial bargaining efforts relative to these matters may be when the provisions are first incorporated into collective agreements. Thus, after the first round or two of bargaining, salaries might be expected to receive greater attention. Finally, given the enormous interest in the question of union-nonunion wage differentials since unionization first became a major force in the workplace (Hamermesh and Rees, 1984), it seems appropriate to explore this question in the context of Canadian universities.

This paper examines the relationship between faculty unionization and wage differentials among the universities in one province, Ontario, concentrating upon the period between 1975-76 and 1983-84. While certain methodological limitations will be noted in the next section, three limitations are of such significance as to be highlighted forthwith. The most serious obstacle to any attempt to determine the effect of unionization on wage rates is that in a partially unionized industry, nonunion employers may pay competitive wages in order to forestall unionization of their own employees. Thus, wage differentials between union and nonunion universities may underestimate the impact of unions on wage rates, as unionization 
may exert an indirect stimulus to increasing wages throughout the entire university system.

Second the categorizing of universities into those which have certified faculty bargaining units (as union) and those which do not (as nonunion) may underestimate the extent of de facto unionization. Non-certified groups which bargain with the university on behalf of the faculty may display many of the characteristics of unions, and their "discussions" with their employers may be quite similar to the collective bargaining negotiations of the certified groups. Further, the salary arbitration provisions extended to one nonunion faculty association, the University of Toronto (see Connell, 1987), may give that group greater leverage in bargaining than is the case for the union groups, which generally do not have compulsory interest arbitration.

Third, during the period under investigation, university faculty in Ontario were subject to financial constraints which effectively limited the rates of wage increases which could be bargained. The effect of wage controls - the Federal Anti-Inflation Program from 1975 to 1979, and the Provincial Restraint Program from 1982 to 1984 - was likely to constrain variation in most kinds of wage differentials, including those between union and nonunion institutions. In addition, throughout most of the period in question, Ontario universities were operating under conditions of declining real operating grants, another factor which constrained the variation in wage increases that could reasonably be bargained. Carrigan suggested that in such a period, much bargaining effort might be expected to go into "novel contract clauses" to compensate for the expected lower salary settlements resulting from financial restraint (p. 80). In short, the period during which those Ontario university faculty associations that have become certified did so has been characterized by forces which likely limited the possibilities for transforming unionization into above average salary gains.

\section{Methodology}

This study will examine average annual salary data for all ranks of faculty in fifteen Ontario universities. Seven of these institutions have certified faculty bargaining units, while eight do not. Faculty associations of the fifteen institutions are members of the Ontario Confederation of University Faculty Associations (OCUFA). The Ontario College of Art; the three satellite campuses of Laurentian University, Algoma, Nipissing and Hearst; and the Ontario Institute for Studies in Education were not included because they are so different from the fifteen universities. Ryerson Polytechnical Institute was not included as it is not a member of OCUFA. Table 1 gives a listing of the institutions included in the study.

Various comparisons are made between the two groups of institutions, including analysis by rank ordering and percentage gain in salary. A closer examination is made of the lecturer and assistant professor ranks, expressing their average salary as a fraction of that of a full professor. The rank of associate professor, specifically the age group 40-44, is examined in terms of salary gains in the union 


\begin{tabular}{|c|c|c|}
\hline \multicolumn{3}{|l|}{ Brock University } \\
\hline \multicolumn{3}{|l|}{ University of Guelph } \\
\hline \multicolumn{3}{|l|}{ McMaster University } \\
\hline \multicolumn{3}{|l|}{ Queen's University } \\
\hline \multicolumn{3}{|l|}{ University of Toronto } \\
\hline \multicolumn{3}{|l|}{ University of Waterloo } \\
\hline \multicolumn{3}{|c|}{ University of Western Ontario } \\
\hline \multicolumn{3}{|c|}{ Wilfrid Laurier University } \\
\hline Unionized Faculty & Certification Date* & Start Date of 1st Contract* \\
\hline Carleton University & June 1975 & July 1,1975 \\
\hline University of Windsor & April 1976 & July 1,1976 \\
\hline University of Ottawa & January 1977 & April 22, 1976 \\
\hline York University & October 1977 & July 1,1976 \\
\hline Laurentian University & July 1979 & July 1,1980 \\
\hline Lakehead University & September 1979 & June 30,1979 \\
\hline Trent University & June 1980 & April 9, 1981 \\
\hline
\end{tabular}

* Source: Ontario Labour Relations Board

and nonunion categories as this rank and age group was identified by OCUFA staff as representing the "typical" Ontario university professor.

Three specific academic years provide the main time reference for the analysis of data, 1975-76, 1981-82 and 1983-84. The base year of 1975-76 represents a year in which six of the seven subsequently unionized universities did not as yet have certified faculty unions. This is also the first year in which comprehensive salary data for the fifteen institutions are available. (Carleton University was the first to unionize, in June of 1975. It was hoped to have used 1974-75 as the base year, but consistent data were not available for that year.) The second year, 1981-82, represents the point in time at which the seven institutions which presently have faculty unions had attained certification. Since the literature on faculty collective bargaining (e.g., Jones, 1986; Kelly, 1979) suggests that the 
Table 2

Scale Increases

\begin{tabular}{|c|c|c|c|c|c|c|c|c|c|c|c|c|c|}
\hline Nonunion & $1972-73$ & $1973-74$ & $1974-75$ & $1975-76$ & $1976-77 \quad 1$ & $1977-78$ & $1978-79$ & $1979-80$ & $1980-81$ & $1981-82$ & $1982-83$ & $1983-84$ & $1984-85$ \\
\hline Brock & 2.50 & 2.20 & 5.80 & 11.60 & 8.90 & 6.80 & 3.00 & 5.00 & 7.00 & 10.80 & 11.00 & 5.00 & 3.00 \\
\hline Guelph & 3.60 & 3.70 & 9.00 & 11.00 & 9.00 & 6.30 & 4.00 & 6.20 & 8.30 & 9.60 & 11.00 & 5.00 & 3.69 \\
\hline McMaster & 3.40 & 3.50 & 6.90 & 11.30 & 8.10 & 6.00 & 3.00 & 5.10 & 7.50 & 10.10 & 11.50 & 5.00 & 2.50 \\
\hline Queen's & 3.50 & 3.50 & 7.30 & 11.80 & 8.20 & 5.50 & 2.50 & 4.60 & 7.70 & 8.50 & 11.00 & 5.00 & 3.10 \\
\hline Toronto & 3.00 & 3.50 & 7.00 & 11.90 & 7.80 & 6.00 & 3.80 & 5.40 & 8.00 & 9.10 & 12.00 & 5.00 & \\
\hline Waterloo & 2.40 & 3.40 & 6.50 & 11.40 & 9.10 & 7.50 & 2.50 & 5.10 & 8.00 & 10.10 & 10.25 & 5.00 & 2.36 \\
\hline Western & 3.80 & 3.50 & 6.00 & 11.40 & 7.80 & 7.30 & 6.00 & 5.00 & 7.50 & 9.00 & 9.00 & 5.00 & 4.00 \\
\hline W.L.U. & 3.10 & 4.40 & 8.50 & 11.60 & 8.50 & 7.50 & 4.20 & 5.40 & 6.80 & 8.60 & 9.00 & 5.00 & 4.10 \\
\hline Average & & & & & & & & & & 9.50 & 10.60 & 5.00 & 3.30 \\
\hline \multicolumn{14}{|l|}{ Union } \\
\hline Carleton & 5.00 & 7.00 & 8.50 & $18.00 *+$ & 9.70 & 5.60 & 2.80 & 5.50 & 4.60 & 6.00 & 12.50 & 5.00 & 5.70 \\
\hline Lakehead & 3.10 & 4.00 & 7.00 & 5.00 & 8.50 & 6.50 & 2.50 & $*+$ & & 9.20 & 9.20 & 5.00 & 2.00 \\
\hline Laurentian & & 5.00 & 8.50 & 12.10 & 10.00 & 6.90 & 3.00 & $5.00+$ & $6.50 *$ & 9.30 & 8.60 & 5.00 & 3.20 \\
\hline Ottawa & 3.70 & 4.00 & 7.60 & 9.00 & $10.80^{*}+$ & 7.00 & 6.00 & 5.60 & 8.00 & 10.00 & 11.50 & 5.00 & 2.80 \\
\hline Trent & 4.70 & 3.50 & 6.50 & 10.10 & 4.70 & 9.50 & 2.30 & 5.00 & $7.00+$ & $12.00 *$ & 11.80 & 5.00 & 3.30 \\
\hline Windsor & 2.00 & 2.30 & 7.00 & 11.00 & $6.70^{*+}$ & 6.90 & 6.60 & 5.50 & 5.50 & 10.00 & & 5.00 & 5.00 \\
\hline York & 4.60 & 4.30 & 7.00 & 10.50 & $8.80^{*}$ & $6.50+$ & 2.00 & 7.20 & 5.20 & 11.50 & 10.45 & 5.00 & 3.60 \\
\hline Average & & & & & & & & & & 9.70 & 10.70 & 5.00 & 3.60 \\
\hline Total & 3.45 & 3.85 & 7.27 & 11.17 & 8.47 & 6.65 & 3.62 & 5.40 & 6.97 & 9.41 & 10.61 & 5.00 & 3.53 \\
\hline $\begin{array}{l}\text { Weighted } \\
\text { Average }\end{array}$ & 3.20 & 3.60 & 7.20 & 11.40 & 8.50 & 6.50 & 3.80 & 5.50 & 7.30 & 9.10 & 10.70 & 5.00 & \\
\hline $\begin{array}{l}\text { CPI for Prev. } \\
\text { Yr (Jul-Jun) }\end{array}$ & 4.1 & 5.8 & 9.4 & 11.2 & 9.8 & 6.7 & 8.8 & 9.1 & 9.3 & 11.6 & 12.0 & 8.3 & 4.9 \\
\hline
\end{tabular}


principal effects of unionization occur shortly after certification, our analysis concentrates on the period ending in 1983-84. However, in the concluding section of the paper, we examine changes which occurred between 1983-84 and 1985-86, the latest year for which we had complete information.

Certain limitations of the analysis should be noted. First, the analysis is restricted to average salaries and does not consider variance within age and rank categories. Second, the data pertain only to full-time faculty. Third, the analysis focuses exclusively on salaries and does not consider other gains which faculty may have achieved over this time period, such as with respect to benefit plans, job security, or sabbaticals. Fourth, the only personal characteristics of faculty for which data are available are age and rank. This may not be too serious a limitation, though, since age and rank explain a substantial proportion of salary variation.

The relationship between age and salary warrants some comment. If changes in age structure differ considerably among institutions, then comparisons of average growth of salaries across the age spectrum could be misleading. As the unionized group includes a disproportionate number of newer universities, it is possible that this group might have experienced relatively more hiring of junior faculty, at lower salaries. If that were the case, comparisons of trends in the all-age average salary would underestimate the effect of unionization on salaries. One way of dealing with this problem would be to make all calculations of salaries trends age-specific. However, this would require extremely elaborate tables and an awesome volume of data.

We have instead approached the problem in a different way. First, we calculated the age distributions for the various years and looked to see if any institutions showed significant deviations from the provincial trends in age-structure, comparing also the union with the nonunion group. Then we calculated an age-adjusted average salary for each institution for 1983-84, applying its 1975-76 age distribution to its $1983-84$ average salary for each age category.

\section{Description of Data}

The average salary of Ontario university faculty by age group, and university, for each rank and all ranks combined, provide the raw data for this study. The data, which are relatively complete, are for both males and females, faculty in all disciplines except medical and dental faculties, and faculty with and without senior administrative duties. The data were obtained from OCUFA which, in turn, obtained the data from Statistics Canada (1975-76; 1981-82;1983-84); and for 1985-86 from Connell (1987).

\section{Analysis}

Table 1 lists the universities included in this study, those with faculty unions and those without. For those with unionized faculty, the date of certification and also the beginning date of the first union negotiated contract are given.

The scale increases in terms of the average percentage salary increase given annually to all faculty are shown in Table 2. For unionized institutions, the year of 
certification is marked with a cross (+), and the beginning date of the first union contract is marked with an asterisk $\left(^{*}\right)$.

Attention is drawn to 1975-76, when Carleton University's faculty unionized and began their first contract with a scale increase of $18 \%$ that year. The average for the year was $11.40 \%$

In 1976-77, the University of Ottawa faculty certified and entered into a contract that granted them an increase of $10.8 \%$, while the yearly average was $8.5 \%$. However, in that same year, Laurentian University faculty, not as yet unionized, were granted an increase of $10 \%$. Also, Windsor faculty, in their first contract, received a salary increase that was nearly two percentage points below the average for the system.

In 1977-78, Trent, at the time not unionized, received an annual scale increase of $9.5 \%$, while the average overall was $6.5 \%$.

In 1978-79, both the University of Western Ontario, with no faculty union, and the University of Ottawa, unionized, were granted increases of 6\%; the University of Windsor, unionized, an increase of $6.6 \%$ while the yearly average was only $3.8 \%$. York University in $1979-80$ received the highest scale increase, with $7.2 \%$ in a year when the average was $5.5 \%$

In 1980-81, three institutions without faculty unions, Guelph, Toronto, and Waterloo, received increases of at least eight per cent. Ottawa, with a faculty union, also registered eight per cent, but other nonunionized universities had increases that were less than the system average. This was also the year of Trent University's unionization. Its first contract began on April 9, 1981, and its salary increase in 1981-82 was $12 \%$ in a year in which the system average increase was just over nine per cent.

Analysis of Table 2 does not indicate any uniform patterns in wage increases between the union and nonunion groups. In certain cases (Carleton, Ottawa, and Trent), faculty received the higher than normal salary increases in first contracts which have been reported elsewhere (Kelly, 1979). However, in other cases, wage gains in first contracts were less than average. There are no indications that the higher than average increases for the former group continued consistently.

From Table 3, which gives a rank ordering of the average increase of 1983-84 salary over 1975-76 salary, one can note a general gain for the institutions with faculty unions over those without faculty unions. Five of the six institutions showing the largest increase over the time period were unionized. The institutions with the highest salary ranks (such as Toronto, Waterloo, McMaster, Queen's) show moderate to low percentage increases over the time period, but no loss in terms of salary rank. They did not make the strongest gains, but they remained the highest paid. The largest relative gains generally were made by those with the lowest salary ranks, especially Carleton, Lakehead, and Trent.

The University of Windsor, Laurentian and Brock show a decline in salary rank over the time period. Windsor dropped from 8th to 10th, Laurentian from 12th to 
17 Faculty Unionization and Salary Differentials in Ontario Universities

Table 3

Rank Ordering of Average Increase of 1983-84 Salary over 1975-76 Salary

\begin{tabular}{|c|c|c|c|c|c|c|c|}
\hline Rank & Institution & $\begin{array}{l}\text { Union- } \\
\text { ized }\end{array}$ & $\begin{array}{l}\text { \# of } \\
\text { years }\end{array}$ & $\begin{array}{l}\mathrm{N} \text { in } \\
\text { unionized }\end{array}$ & $\begin{array}{c}\text { Salary } \\
1975-76\end{array}$ & $\begin{array}{l}\text { Ranik } \\
1983-84\end{array}$ & \% Increase \\
\hline 1 & Carleton & $\mathrm{x}$ & 8 & & 14 & 8 & 117.7 \\
\hline 2 & York & $\mathrm{x}$ & 6 & & 9 & 9 & 103.9 \\
\hline 3 & Lakehead & $\mathrm{x}$ & 4 & & 15 & 13 & 101.7 \\
\hline 4 & W.L.U. & & & $\mathrm{x}$ & 11 & 11 & 101.5 \\
\hline 5 & Trent & $\mathrm{x}$ & 3 & & 13 & 12 & 100.7 \\
\hline 6 & Ottawa & $x$ & 6 & & 7 & 6 & 97.7 \\
\hline 7 & Toronto & & & $x$ & 1 & 1 & 97.0 \\
\hline 8 & Waterloo & & & $\mathrm{x}$ & 2 & 2 & 96.5 \\
\hline 9 & Western & & & $\mathrm{x}$ & 6 & 7 & 92.8 \\
\hline 10 & Guelph & & & $\mathrm{x}$ & 5 & 5 & 91.0 \\
\hline 11 & Windsor & $x$ & 7 & & 8 & 10 & 90.6 \\
\hline 12 & McMaster & & & $x$ & 3 & 3 & 90.4 \\
\hline 13 & Queen's & & & $\mathrm{x}$ & 4 & 4 & 88.1 \\
\hline 14 & Laurentian & $\mathrm{x}$ & 4 & & 12 & 15 & 88.1 \\
\hline 15 & Brock & & & $x$ & 10 & 14 & 87.3 \\
\hline
\end{tabular}

15th, and Brock from 10th to 14th. The first two of these institutions, Windsor and Laurentian, have faculty unions.

An examination of changes in rank ordering between 1975-76 and 1981-82 (Table 4) shows that salary rank was essentially static among the nonunionized institutions as a group. The top five salary ranks belonged to universities in this group. A look at the unionized group reveals that those institutions tended to be at the bottom of the salary ranks in 1975-76. Clearly, the highest paid institutions did not move to unionization, while the lowest paid moved considerably in that direction. Those in the mid-range were split between union and nonunion categories. The tendency for unionization to have occurred primarily in the then lower paid institutions might be taken to suggest that salary enhancement was a larger factor in decisions to unionize than was generally believed by the authors cited earlier. 
Table 4

Rank Order of Salaries Combining All Academic Ranks

\begin{tabular}{|c|c|c|c|c|c|c|c|}
\hline Nonunion & & $\begin{array}{l}\text { Rank in } \\
1975-76\end{array}$ & $\begin{array}{l}\text { Rank in } \\
1981-82\end{array}$ & $\begin{array}{l}\text { Change in } \\
\text { rank over } \\
1975-76\end{array}$ & $\begin{array}{l}\text { Rank in } \\
1983-84\end{array}$ & $\begin{array}{l}\text { Change in } \\
\text { rank over } \\
1981-82\end{array}$ & $\begin{array}{c}\text { Change in } \\
\text { rank over } \\
1975-76\end{array}$ \\
\hline Brock & & 10 & 12 & -2 & 14 & -2 & -4 \\
\hline Guelph & & 5 & 4 & +1 & 5 & -1 & 0 \\
\hline McMaster & & 3 & 2 & +1 & 3 & -1 & 0 \\
\hline Queen's & & 4 & 3 & +1 & 4 & -1 & 0 \\
\hline Toronto & & 1 & 5 & -4 & 1 & +4 & 0 \\
\hline Waterloo & & 2 & 1 & +1 & 2 & -1 & 0 \\
\hline Western & & 6 & 9 & -3 & 7 & +2 & -1 \\
\hline Wilfrid Laurier & & 11 & 11 & 0 & 11 & 0 & 0 \\
\hline Union & $\begin{array}{l}\text { \# of years } \\
\text { unionized }\end{array}$ & & & & & & \\
\hline Carleton & (8) & 14 & 10 & +4 & 8 & +2 & +6 \\
\hline Lakehead & (4) & 15 & 13 & +2 & 13 & 0 & +2 \\
\hline Laurentian & (4) & 12 & 14 & -2 & 15 & -1 & -3 \\
\hline Ottawa & (6) & 7 & 6 & +1 & 6 & 0 & +1 \\
\hline Trent & (3) & 13 & 15 & -2 & 12 & +3 & +1 \\
\hline Windsor & (7) & 8 & 8 & 0 & 10 & -2 & -2 \\
\hline York & (6) & 9 & 7 & +2 & 9 & -2 & 0 \\
\hline
\end{tabular}

Table 5 displays the percentage increase in average salary for all ranks combined, comparing the years $1975-76,1981-82$, and 1983-84. Of note is the general tendency for the unionized universities to gain more over the time period than those without faculty unions. Wilfrid Laurier, however, a non-unionized university, outperformed four of the seven institutions with faculty unions with its overall gain of $101.5 \%$ from 1975-76 to 1983-84. It appears also that the relative gains for the non-unionized universities occurred prior to 1982 . This is perhaps not surprising because 1982 to 1984 were the years of the Provincial Restraint Program, a factor which likely contributed to salary compression.

Table 5 shows also a considerable widening of average salary differentials in absolute dollars. The difference between the highest (Toronto) and lowest (Lakehead) in 1975-76 was about five thousand dollars. By 1983-84, this difference was just under nine thousand, and more that ten thousand between Toronto and Laurentian - which had replaced Lakehead as the lowest paid. 
Table 5

Percentage Gain in Average Salary* - All Ranks Combined

\begin{tabular}{|c|c|c|c|c|c|c|}
\hline Nonunion & $\begin{array}{c}(1) \\
1975-76\end{array}$ & $\begin{array}{c}(2) \\
1981-82\end{array}$ & $\begin{array}{l}\% \text { gain } \\
\text { (2) over (1) }\end{array}$ & $\begin{array}{c}(3) \\
1983-84\end{array}$ & $\begin{array}{l}\% \text { gain } \\
\text { (3) over (2) }\end{array}$ & $\begin{array}{c}\% \text { gain } \\
\text { (3) over (1) }\end{array}$ \\
\hline Brock & $\$ 21772$ & $\$ 36051$ & 65.6 & $\$ 40785$ & 13.1 & 87.3 \\
\hline Guelph & 24400 & 40156 & 64.6 & 46610 & 16.1 & 91.0 \\
\hline McMaster & 25270 & 40674 & 61.0 & 48108 & 18.3 & 90.4 \\
\hline Queen's & 24942 & 40429 & 62.1 & 46912 & 16.0 & 88.1 \\
\hline Toronto & 25352 & 40009 & 57.8 & 49946 & 24.8 & 97.0 \\
\hline Waterloo & 25316 & 42504 & 67.9 & 49743 & 17.0 & 96.5 \\
\hline Western & 23608 & 38296 & 62.2 & 45513 & 18.8 & 92.8 \\
\hline Wilfrid Laurier & 21712 & 36573 & 68.4 & 43748 & 19.6 & 101.5 \\
\hline Average & & & $(63.7)$ & & $(18.0)$ & $(93.1)$ \\
\hline \multicolumn{7}{|l|}{ Union } \\
\hline Carleton & 20898 & 36885 & 76.4 & 45489 & 23.4 & 117.7 \\
\hline Lakehead. & 20330 & 34775 & 71.1 & 40998 & 17.9 & 101.7 \\
\hline Laurentian & 21016 & 34508 & 64.2 & 39536 & 14.6 & 88.1 \\
\hline Ottawa & 23376 & 39696 & 69.8 & 46220 & 16.4 & 97.7 \\
\hline Trent & 20924 & 33442 & 59.8 & 41998 & 25.6 & 100.7 \\
\hline Windsor & 23114 & 38633 & 67.1 & 44044 & 14.0 & 90.6 \\
\hline York & 22302 & 39086 & 75.3 & 45464 & 16.3 & 103.9 \\
\hline Average & & & $(69.1)$ & & $(18.3)$ & $(100.1)$ \\
\hline
\end{tabular}

* Figures not adjusted for inflation

Penner (p. 80) has suggested that one of the primary goals of faculty unions has been to bring greater equity to internal salary distributions. One aspect of internal equity might involve relationships among the salaries for different ranks. Table 6, displaying the salary of an assistant professor at each institution as a proportion of that of a full professor, reveals a small shift in the relative salary for the lower rank. The nonunion group moved from $57.8 \%$ in $1975-76$ to $60.0 \%$ in 1983-84; the unionized group moved from $60.4 \%$ to $62.6 \%$; the difference in each case is identical, $2.2 \%$. There was a decrease in the relative salary of assistant professor for one institution in each group (Toronto and Windsor). For each group, the largest gain in relative salary for assistant professor was made in the institution 
Table 6

Salary of Assistant Professors Expressed as a Percentage of Full Professors

\begin{tabular}{lccc}
\hline Nonunion & $1975-76$ & $1981-82$ & $1983-84$ \\
\hline Brock & 60.6 & 61.8 & 61.3 \\
Guelph & 57.8 & 57.7 & 59.7 \\
McMaster & 60.5 & 60.4 & 61.7 \\
Queen's & 57.1 & 58.7 & 59.8 \\
Toronto & 57.0 & 53.2 & 55.4 \\
Waterloo & 55.9 & 58.0 & 60.2 \\
Western & 57.5 & 58.2 & 59.3 \\
Wilfrid Laurier & 55.9 & 60.3 & 62.8 \\
Average & 57.8 & 58.5 & 60.0 \\
\hline Union & & & \\
\hline Carleton & 60.8 & 62.0 & 66.0 \\
Lakehead & 63.5 & 66.0 & 65.8 \\
Laurentian & 62.1 & 64.5 & 63.2 \\
Ottawa & 59.7 & 62.6 & 61.9 \\
Trent & 58.0 & 61.8 & 58.5 \\
Windsor & 64.1 & 59.8 & 63.0 \\
York & 54.9 & 69.7 & 62.6 \\
Average & 60.4 & & \\
\hline
\end{tabular}

which had the greatest overall increase in salaries - Wilfrid Laurier in the nonunion, and Carleton in the union group, suggesting that more rapid salary increase may be associated with greater reduction of salary differentials. The corresponding data for the lecturer rank (not shown here) indicates virtually the same pattern as for assistant professor, with the ratio increasing from 50.3 to 52.4 for the union group and from 47.2 to 49.4 for the nonunion group. Thus, there was no significant difference between the two groups with respect to trends toward greater compression of salaries among ranks.

Table 7 shows the percentage increase over the three periods in average salary of an associate professor aged 40-44. Of note in the nonunion group is the poor 


\section{Table 7}

Percentage Increase in Average Salary of Associate Professor - 40-44 age group

\begin{tabular}{|c|c|c|c|c|c|c|}
\hline Nonunion & $\begin{array}{c}(1) \\
1975-76\end{array}$ & $\begin{array}{c}(2) \\
1981-82\end{array}$ & $\begin{array}{l}\% \text { gain } \\
\text { (2) over (1) }\end{array}$ & $\begin{array}{c}(3) \\
1983-84\end{array}$ & $\begin{array}{l}\% \text { gain } \\
\text { (3) over (2) }\end{array}$ & $\begin{array}{l}\% \text { gain } \\
\text { (3) over (1) }\end{array}$ \\
\hline Brock & $\$ 23180$ & $\$ 35199$ & 51.9 & $\$ 39516$ & 12.3 & 70.5 \\
\hline Guelph & 23659 & 37527 & 58.6 & 43449 & 15.8 & 83.6 \\
\hline McMaster & 24372 & 39883 & 63.6 & 44929 & 12.6 & 84.3 \\
\hline Queen's & 24683 & 35906 & 45.5 & 41538 & 15.7 & 68.3 \\
\hline Toronto & 24084 & 38237 & 58.8 & 45630 & 19.3 & 89.5 \\
\hline Waterloo & 24916 & 40595 & 62.9 & 46869 & 15.5 & 88.1 \\
\hline Western & 23940 & 38004 & 58.7 & 42925 & 12.9 & 79.3 \\
\hline Wilfrid Laurier & 22046 & 38422 & 74.3 & 43315 & 12.7 & 96.5 \\
\hline Range & 2870 & 5396 & & 7353 & & \\
\hline (Average) & & & & & $(14.6)$ & $(82.5)$ \\
\hline \multicolumn{7}{|l|}{ Union } \\
\hline Carleton & 20749 & 34981 & 68.6 & 41759 & 19.4 & 101.3 \\
\hline Lakehead & 21924 & 34746 & 58.5 & 39912 & 14.9 & 82.0 \\
\hline Laurentian & 23896 & 38504 & 61.1 & 42292 & 9.8 & 77.0 \\
\hline Ottawa & 24405 & 39518 & 61.9 & 44585 & 12.8 & 82.7 \\
\hline Trent & 21739 & 33129 & 52.4 & 39944 & 20.5 & 83.7 \\
\hline Windsor & 22741 & 35329 & 55.4 & 39766 & 12.6 & 74.9 \\
\hline York & 22325 & 36878 & 65.2 & 42075 & 14.1 & 88.5 \\
\hline Range & 3656 & 6389 & & 4819 & & \\
\hline (Average) & & & & & $(14.9)$ & $(84.3)$ \\
\hline
\end{tabular}

performance of Queen's, with an overall increase from the base year of $68.3 \%$, and also that of Brock with $70.5 \%$. The average for the group was $82.5 \%$. In the group with faculty unions, the high performer is Carleton University, with an overall percentage increase from the base year of $101.3 \%$, while the group average was $84.3 \%$. The salary increase for the nonunionized group was only slightly below that for the unionized group, and the second and third largest increases (Wilfrid Laurier and Toronto) were in the nonunion group. 
Table 8

Percentage Gain in Average Salaries Adjusted for Change in Age Distribution, All Ranks - 1975-76 to 1983-84

\begin{tabular}{lccccc}
\hline Nonunion & $\begin{array}{c}(1) \\
1975-76\end{array}$ & $\begin{array}{c}(2) \\
1983-84 \text { adj }\end{array}$ & $\begin{array}{c}(3) \\
\% \text { gain }\end{array}$ & $\begin{array}{c}(4) \\
\text { unadj gain }\end{array}$ & $\begin{array}{c}(5) \\
\text { difference }\end{array}$ \\
\hline Brock & $\$ 21772$ & $\$ 36993$ & 69.9 & 87.3 & $20 \%$ \\
Guelph & 24400 & 43709 & 79.1 & 91.0 & $13 \%$ \\
McMaster & 25270 & 43263 & 71.2 & 90.4 & $21 \%$ \\
Toronto & 25352 & 46382 & 83.0 & 97.0 & $14 \%$ \\
Waterloo & 25316 & 44894 & 77.3 & 96.5 & $20 \%$ \\
Western & 23608 & 41533 & 75.9 & 92.8 & $18 \%$ \\
W.L.U. & 21712 & 41416 & 90.8 & 101.5 & $11 \%$ \\
Average & & & 78.2 & 93.8 & $17 \%$ \\
\hline Union & & & & & $1 \%$ \\
\hline Carleton & 20898 & 41758 & 99.8 & 117.7 & $15 \%$ \\
Lakehead & 20330 & 37397 & 83.9 & 101.7 & $18 \%$ \\
Laurentian & 21016 & 35561 & 69.2 & 88.1 & $21 \%$ \\
Ottawa & 23376 & 43196 & 84.8 & 97.7 & $13 \%$ \\
Trent & 20924 & 36318 & 73.6 & 100.7 & $27 \%$ \\
Windsor & 23114 & 40448 & 75.0 & 90.6 & $17 \%$ \\
York & 39693 & 78.0 & 103.9 & $25 \%$ \\
Average & & & 80.6 & 100.1 & $19 \%$ \\
\hline
\end{tabular}

Column (2) is obtained by applying the 1975-76 age distribution to the 1983-84 salaries by age category.

Column ( 3 ) is the percentage change in average salaries adjusted for changes in age distribution.

Column (4) is the unadjusted change in average salaries taken from Table 5.

Column $(5)=(4)-(3)$ as a percentage of $(4)$.

Note: Data for Queen's for 1975-76 were not available.

The relatively small difference between the union and nonunion groups with regard to the change in salary for the associate professor aged 40-44 suggests that changes in the age distribution may have had a moderating influence on union-nonunion differentials in average salaries. We found this indeed to be the case. Table 8 shows that when control is made for changes in the age distribution that occurred between 1975-76 and 1983-84, the margin of gain for the union group over the nonunion group falls from about six per cent to about two per cent. The adjustment for age makes the greatest difference for Trent and York, and, in the opposite direction, for Wilfrid Laurier. Inspection of changes in the percentage distribution by age indicates a substantially smaller percentage of faculty in the under 30 and 30-34 categories for Trent and the 30-34 category for York in 1983-84 compared to 1975-76. The implication is that, relative to other 
Table 9

Changes in Average Salary, All Ranks, $1983-84$ to $1985-86$

\begin{tabular}{|c|c|c|c|c|c|c|}
\hline Nonunion & $1985-86$ & 1983-84 & Change & $\begin{array}{c}\text { Rank } \\
1983-84 \\
\end{array}$ & $\begin{array}{c}\text { Rank } \\
1985-86\end{array}$ & $\begin{array}{l}\text { Change } \\
\text { in Rank }\end{array}$ \\
\hline Brock & $\$ 43273$ & $\$ 40785$ & 6.10 & 14 & 15 & -1 \\
\hline Guelph & 49245 & 46610 & 5.65 & 5 & 9 & -4 \\
\hline McMaster & 52931 & 48108 & 10.03 & 3 & 3 & 0 \\
\hline Queen's & 49304 & 46912 & 5.10 & 4 & 8 & -4 \\
\hline Toronto & 54999 & 49946 & 10.12 & 1 & 1 & 0 \\
\hline Waterloo & 53430 & 49743 & 7.41 & 2 & 2 & 0 \\
\hline Western & 50437 & 45513 & 10.82 & 7 & 5 & 2 \\
\hline \multirow[t]{2}{*}{ W.L.U. } & 44431 & 43748 & 1.56 & 11 & 13 & -2 \\
\hline & & & 7.10 & & & -9 \\
\hline \multicolumn{7}{|l|}{ Union } \\
\hline Carleton & 50856 & 45489 & 11.80 & 8 & 4 & 4 \\
\hline Lakehead & 45202 & 40998 & 10.25 & 13 & 11 & 2 \\
\hline Laurentian & 43899 & 39536 & 11.04 & 15 & 14 & 1 \\
\hline Ottawa & 50075 & 46220 & 8.34 & 6 & 7 & -1 \\
\hline Trent & 44866 & 41998 & 6.83 & 12 & 12 & 0 \\
\hline Windsor & 48365 & 44044 & 9.81 & 10 & 10 & 0 \\
\hline \multirow[t]{2}{*}{ York } & 50430 & 45464 & 10.92 & 9 & 6 & 3 \\
\hline & & & 9.86 & & & 9 \\
\hline
\end{tabular}

institutions, Trent and York did substantially less hiring of younger faculty between 1975 and 1983 than they did prior to 1975. Wilfrid Laurier, on the other hand, was the only university that did not have an increase in the relative number in the 55-59 category over the period in question, possibly reflecting a peculiarity of its age structure some years earlier. At any rate, the apparent small gain from unionization in Table 5 practically disappears when adjustment is made for age.

\section{Conclusions}

The analysis does not suggest that faculty unionization has resulted in a significant alteration of salary patterns among Ontario universities during the most active period of faculty certification. The increase in average salary for the associate professor, aged 40-44, for the union group exceeded that of the nonunion group by less than two percentage points. While the average for all ranks and ages for the 
union group grew by about seven percentage points more than that for the nonunion group, when adjustment is made for changes in age distribution the margin is reduced to about two percentage points - consistent with findings in the United States which indicate that the effect of unionization on inter-institutional differences in salaries is in the zero to five per cent range. The five highest ranking institutions, all nonunionized, were the same at the end of the period as at the beginning, and the absolute differential between the highest and the lowest ranking increased from about five thousand dollars to about ten thousand. Perhaps the most significant difference between the two groups is that Carleton, the first to unionize moved up six notches in the rank ordering, while one nonunionized institution, Brock, moved down four notches.

This conclusion about the limited effect of unionization upon salary differentials must be qualified by reference to the conceptual limitations noted earlier. The nonunionized employers may emulate the settlements at the unionized institutions, and certification may not be a very precise indicator of the extent of de facto unionization. All the university faculty groups examined in this paper belong to the Ontario Confederation of University Faculty Associations, and the tendency of bargaining team members from both the union and nonunion groups to meet together to compare bargaining strategies and bargaining outcomes likely has the effect of compressing the range of settlements - as does the tendency of those on the other side of the bargaining table to do likewise through the Council of Ontario Universities. Further, the financial constraints to which all Ontario universities have been subjected over the past decade no doubt have worked to constrain variation in salary settlements. As one might expect, we found almost no change in salary differentials during the 1982-84 period of provincial wage controls.

Interest in the possible effects of the removal of these controls led us to examine changes between 1983-84 and the latest year for which we could obtain the relevant data, 1985-86. Table 9 shows that the average increase for the union group exceeded that for the nonunion group by close to three percentage points; but two years is too short a period from which to attempt to extrapolate any trends in this regard. More noteworthy is that Carleton has continued its ascent in the standings and has now moved into the top five, with York following close behind. On the other hand, both Guelph and Queen's fell from the top five to just below the middle of the rank ordering.

While we have tended to concentrate our discussion on the differences in the experiences of the two groups, union and nonunion, the within group variation in salary increase appears to have been substantially greater than the between group variation. When one contrasts the large gains made by Carleton with the relative decline for Laurentian and Windsor, and the little movement for Lakehead or Trent, or the decline for Brock with slight gain for Western, one is led to wonder if other factors unique to a particular institutional environment are not more important in determining relative salary levels than the existence of unionization. In the absence of more literature on salary determination and collective bargaining in Canadian universities, there are few clues as to what these other factors might 
be, or how they might be incorporated into analytical models of salary determination. What would perhaps be most useful for advancing research on the question to which this paper is addressed would be comparative case studies of the salary determination process - for example, comparing Carleton with Windsor or Laurentian, or Brock with Western - which might identify factors that, in turn, could be incorporated into multivariate analyses of salary differences among Ontario universities, with a view toward isolating the particular effect of unionization.

\section{REFERENCES}

Adell, B., \& Carter, D.D. (1972). Collective Bargaining for University Faculty in Canada. Kingston: Industrial Relations Centre, Queen's University.

Baldridge, J.V., Kemerer, F.R. \& others. (1985). Assessing the Impact of Faculty Collective Bargaining. In M.J. Finklestein (Ed.), ASHE Reader on Faculty Issues in Colleges and Universities. Washington, D.C.: Association for the Study of Higher Education, 265-276.

Carrigan, D.O. (1977). Unionization in Canadian Universities. International Journal of Institutional Management in Higher Education (1). 17-31.

Connell, G.E. (1987). Comments to Governing Council Re: Salary Determination for UTFA 1986-87. University of Toronto Bulletin, January 26, Exhibit 2b, p. 53.

Freeman, R. (1987). Should We Organize? Effects of Faculty Unionism on Academic Compensation. Working Paper No. 301. Cambridge, MA: National Bureau of Economic Research.

Garry C. (1978). Toward a Sociological Theory of Labour Relations. Canadian Journal of Higher Education, 8 (1), $61-77$.

Hamermesh, D.S. \& Rees, A. (1984). The Economics of Work and Pay, 3rd ed. New York: Harper and Row.

Jones, L.L. (1986). The Impact of Faculty Unions on Higher Education: A Reconsideration. Public Personnel Management, 15 (2), 181-188.

Kelly, E. (1979). Collective Bargaining in Higher Education. In J. Young (Ed.), Proceedings of the National Conference on the Impact of Collective Bargaining on the Quality of Education Today. Amherst, MA: Center for the Study of Collective Bargaining in Education, University of Massachusetts.

Murray, J.G. (1985). Power and Politics in Academe: Faculty Unionism in Ontario. Doctor of Education Dissertation, University of Toronto.

Penner, R. (1978-79). Faculty Collective Bargaining in Canada: Background, Development, and Impact. Interchange, 9 (3), 71-86.

Ponak, A., \& Thompson, M. (1983). Faculty Views of Collective Bargaining at Westem Canadian Universities. In Proceedings of the Nineteenth Annual Meeting of the Canadian Industrial Relations Association.

Savage, D.C. (1983). An Insider's View of Canadian Bargaining. Academe, November-December, 16-20.

Skolnik, M.L., \& Rowen, N. (1984). "Please Sir, I Want Some More": Canadian Universities and Financial Restraint. Toronto: OISE Press.

Statistics Canada (1975-76, 1981-82, and 1983-84). Salary Analysis of Full Time Teaching Staff at Canadian Universities. Ottawa: Education, Science, and Culture Division, Statistics Canada. 